\title{
Water management at the Alhambra: A late medieval study
}

\author{
April L. Najjaj \\ Gulf University of Science and Technology, Kuwait \\ najiaj.a@gust.edu.kw
}

\begin{abstract}
The Alhambra is a medieval palace-city that had been the royal residence and seat of government for the Nasrid Kingdom of Granada, the last Islamic dynasty of al-Andalus. With the dynasty's founding in $1238 \mathrm{CE}$, a steady supply of water became a necessity for an expanding palace-city, both in the royal precincts of the site as well as the medina area where the ancillary population resided. Besides basic hygiene, in an Islamic context, water was important for observance of religious obligations as well as a symbol of power and authority for the Nasrid sultans with the many baths, fountains, gardens, and reflecting pools found throughout the Alhambra that are a mark of luxury in an otherwise arid environment. Lastly, in terms of agricultural use, providing for the use and storage of water at the Alhambra was important for cultivation both inside and outside the walls of the palace-city, as well as in the lands surrounding the city of Granada itself. The practical uses of water as well as the symbolism of wealth and power that comes from water control are important for understanding the context of water use and management at the Alhambra.
\end{abstract}

Keywords. Alhambra, cultural studies, water, Nasrid dynasty

The Alhambra is a medieval palace-city that had been the royal residence and seat of government for the Nasrid kingdom of Granada, the last Islamic dynasty of al-Andalus, from the beginnings of the dynasty in $1238 \mathrm{CE}$ until its final defeat some 250 years later. The foundations of the Alhambra date back several centuries earlier, but the site reached its greatest expression, both architecturally and historically, during the fourteenth century when it served as both a royal residence and a seat of government for the Nasrid sultans. After the Christian conquest in 1492, it became an occasional residence for Spanish royalty for the next 150 years, until the state of disrepair and the parceling out of sections as rewards for military service ended at least formal permanent habitation at the site. It was occupied by French troops in the early 1800s, with the medina area suffering heavy damage upon their withdrawal near the end of the Napoleonic wars. After that, occasional visitors came and went until restoration and conservation of the site began in earnest by the 1930s, and it was named a UNESCO World Heritage Site in 1984. Archeological work there is ongoing, and the many tour buses that pull up during the summer months have made the site the number one tourist attraction in Spain today.

Ibn al-Khatib (d. 1374 CE), a wazir to the Nasrid sultans Yusuf I (1333-1354) and Muhammad V (1354 1359; 1361-1391) during much of the $14^{\text {th }}$ Century, gave an exceedingly brief description of the planning and initial stages of habitation of the Alhambra, built to the east of the original fortress of the Alcazaba. He wrote that the founder of the Nasrid dynasty, Muhammad Ibn al-Ahmar (1195-1273 CE), "built the fortress of the Alhambra, conducted the waters to it, and lived in it." (Ibn al-Khatib, 1998). In reality, the process was considerably more complicated, for upon deciding to expand out from the fortress of the Alcazaba, Muhammad I constructed an acequia (an aqueduct) above the site that would service the needs of the future palace-city by diverting water from the nearby Darro River. At some later point in time, the acequia was divided into two separate channels; the first, called the Acequia del Tercio (as one-third of the water traveled through this channel) is located in the upper regions of the Generalife grounds and supplied water 
to extensive vegetable gardens before running down a ravine and is today lost among the hotels and parking lots that have been built above the Alhambra grounds.

The second channel, known as the Acequia Real, provided the water to the palace-city; this channel entered the grounds of the Alhambra from the Generalife and ran the entire length of the palace-city through to the Torres Bermejas and the residential district known as the Antequeruela, both located outside the walls and down the hill from the Alcazaba at the opposite end of the site. ${ }^{1}$ With subsequent archaeological excavations, there is "no doubt that the Alhambra's hydraulic system was created for the construction of the palace city," indicating that the design of the water delivery system pre-dated construction of the palaces and reception halls and courtyards that eventually comprised the Alhambra, yet also continued to be altered to allow for ongoing construction and renovation projects in the $14^{\text {th }}$ Century (Malpica, 2002). In the words of Glick and Kirchner, "design... is the first principle from which all the rest follow," indicating that the hydraulic system, its "plan for articulation,' is in place first and thus serves as the guiding principle for later construction and alterations within the environs of the palace-city (Glick and Kirchner, 2000).

Within the walls itself, the Alhambra contained a variety of storage facilities for water located from one end of the site to the other. Eight cisterns have been found, extending from locations adjacent to the baths at the Palace of the Abencerrajes near a transitional area between the royal and madina areas of the palace-city, and then continuing west through to the Patio of the Lions, the Palace of Charles V, and eventually to the Alcazaba. ${ }^{2}$ In addition, a number of albercas (small reservoirs for water storage) have been found, with one in the medina, several in the environs of the Palace of Charles $\mathrm{V}$ and the rauda gardens, three more in the region of the Comares palace, and an additional two in the underground spaces between the dungeons and the bath area of the Alcazaba. All the albercas throughout the palace-city are smaller than the cisterns, with the exception of the reflecting pool in the Patio of the Myrtles in the reception area leading into the Hall of the Ambassadors. ${ }^{3}$ However, outside the walls of the palace-city and above the Generalife complex is the largest of the albercas, the Albercón de las Damas, which measures approximately $19.4 \mathrm{x}$ 14.2 meters $\left(275.5 \mathrm{~m}^{2}\right)$ and has a maximum capacity of 400 cubic meters of water (Malpica, 2002).

An abundance of water in an otherwise dry and arid climate served as an important symbolic marker of power and authority for rulers throughout the Islamic world, including its western extremes of al-Andalus. Within the multiple residences, reception halls, baths, and gardens of the Alhambra, water can be seen or at least heard in a variety of pools, channels, and fountains at virtually every turn, serving as a reflection of the power and authority of the Nasrid ruler not only within the confines of the palace-city but beyond its walls as well. In al-Lamba, Ibn al-Khatib writes:

\section{The fortress of the Alhambra, the royal court, dominates the population to the south, crowning with its white battlements and its elevated alcazars, that dazzle the eyes and amaze the intelligence. The excess water, and that which overflows from its tanks and pools, falls forming small streams, whose rumor can be heard from far away (Ibn al-Khatib, 1998; Molina and Casciaro, 1998).}

\footnotetext{
${ }^{1}$ See Antonio Malpica (2002, p. 290-307) and Pavón Maldonado (1990). Today, the Acequia Real has been cut at the point the channel enters the Alhambra from the Generalife; a visit by Queen Elizabeth II of England in the 1960s, together with the demands of tourism, resulted in the construction of an additional entrance and of sidewalks and footpaths for tourism. No entrance to the Generalife from the madina area existed during the time of Muslim rule.

2 See diagram included with Basilio Pavón Maldonado (1990). One of these cisterns is visible today in the small museum constructed in a basement located partially below the Palace of Charles V.

${ }^{3}$ Ibid.
} 
Providing water for proper hygiene as well as for ablutions required before prayer in Islam proved to be one of the greatest needs for water in a palace-city. The sultan's legitimacy continued to be based in part upon his role as the religious leader for the kingdom, and part of that responsibility resided in providing the facilities necessary for the proper practice of Islam. Thus, fulfilling the religious obligations of wudu' (ablutions) as many as five times each day before prayers required asteady supply of water for the population of the palace-city. At the Alhambra, a number of baths had been constructed over a prolonged period of time and located throughout the complex for both royal and public use. As many as seven baths existed throughout the site, with one in the Generalife, one in the medina area, several others in the area of the mosque, the royal bath adjacent to the Hall of the Ambassadors, and a last one located in the Alcazaba; however, with the Christian conquest and subsequent expulsion of the Muslim population, the majority of these spaces fell into disuse, and the new inhabitants either renovated these facilities for other uses or destroyed them. ${ }^{4}$

The earliest bath, located in the Alcazaba, measured approximately $322 \mathrm{~m}^{2}$ and had been situated below the plaza level adjacent to the Torre de la Vela and across the street from the aljibe (meaning 'cistern'; from Arabic al-yubb) (Fernández-Puertas, 1997, p. 229). The style and basic construction of this bath is a direct reflection of the original role of the Alcazaba as a fortress for previous dynasties dating back at least to the taifa kingdom of the Zirids in the $11^{\text {th }}$ Century; as such, this bath is more utilitarian, less sophisticated, lacking in ornamentation or inscriptions, and is built on a smaller scale than would be the case at a later date. ${ }^{5}$

With the consolidation of the Nasrid dynasty and subsequent expansion outside the confines of the Alcazaba, more spacious and highly decorative baths can be found in the palace-city. The best preserved is a royal bath constructed by the Nasrid sultan, Muhammad III, and expanded upon by Yusuf I, and is located adjacent to the Court of the Myrtles between the Hall of the Ambassadors and the Hall of the Two Sisters. Measuring approximately $700 \mathrm{~m}^{2}$ and covering two floors, this bath is the largest in the Alhambra and had been ornately tiled and decorated for the use of the royal family and their guests. ${ }^{6}$ The bath included a latrine on the first floor, as well as two other such facilities not far away in the northern area of the Patio of the Lions with one of those located in the passageway between the Patio and the Hall of Two Sisters (Torres-Balbás, 1959).

The non-royal population of the Alhambra had a bath adjacent to the mosque space located in the transitional or marginal zone between the royal spaces of the palace-city and the medina area that contained a market and the residential spaces for service personnel. The entrance to this bath is found on the Calle Real Baja, the principal street of the Alhambra, that ran the length of the palace-city from the medina area in the eastern end to the Alcazaba in the west. Measuring $256 \mathrm{~m}^{2}$, this public bath was the smallest of the three,

\footnotetext{
4 See Pavón (1990) diagram; see also Bermúdez-Pareja, (1974-75).

${ }^{5}$ See Malpica Cuello (2002, p. 90-92). The Torre de la Vela adjacent to the bath in the Alcazaba is one of the less structurally sound areas of the Alhambra complex today; as such, this bath is not open to the public. See Fernández-Puertas, The Alhambra, 181-206.

6 See Bermúdez-Pareja, (1974-75).This hammam is also closed to the public. See also Torres-Balbás (1945); much of this bath had been destroyed by the Christians in 1534, and significant work had been done in the 1930s to rebuild that section of the palace-city.
} 
and although the walls did have some tile work as decoration, the style and density of ornamentation is significantly less than at the royal bathing facilities (Torres-Balbás, 1945). Although separated from each other by only a few hundred yards, these spaces both symbolically and socially existed worlds apart for the common people resident in the medina of the Alhambra.

A second use of water at the site demonstrates the symbolism of power and authority for the sultan in the abundant displays of fountains, channels, and reflecting pools contained in various ornamental gardens located throughout the palace-city. A quite famous (although later) example of such an ornamental space is the Patio of the Lions, built by the Nasrid sultan Muhammad V sometime between 1363 and 1370. Originally containing a sunken garden with the fountain in the center, the patio had also included orange trees, considered in Islamic gardens as only ornamental plants, and, according to Ibn Khaldun, "are the ultimate in sedentary culture, since they are planted in gardens only for the sake of their appearance, and they are planted only after the ways of luxury have become diversified. This is the stage in which one must fear the destruction and ruin of a city ..."7 The garden spaces in the Patio of the Lions are paved over today, but the famous fountain in the center of the patio still bears a poem inscribed around the rim of a large bowl that rests on the backs of twelve lions that emit water from their mouths into a round channel that runs into smaller channels in the four directions of the patio (Nuere, 1986). The poem had been composed by Ibn Zamrak (1333-1393 CE), a Granadan born in the Albaicín who rose quickly through the ranks of the madrasa (Islamic school), and with Ibn al-Khatib as a mentor, Ibn Zamrak became a member of the Nasrid government and accompanied Muhammad V into exile in North Africa in 1359 CE; eventually, not only would he replace Ibn al-Khatibas the wazir but had him assassinated in 1373 after Ibn al-Khatib had fallen out of favor and fled to North Africa. Although Ibn Zamrak claimed to be the author of all the poems found on the walls of the Alhambra, today we know that to have been an exaggeration (García-Gómez, 1975). Within the panegyrical style of the poem itself, it can be seen that the ruler's control of nature extends to referencing water as reflections on the power and authority of the sultan. The fountain and the entire patio had been constructed by Muhammad V-with the help of Allah, of course (as mentioned at the beginning of the poem in stanza 1) - and these references linked to nature and to water, together with the religious and military implications, make for a powerful reference to the Nasrid sultan reflected in the ornamental garden spaces of the Alhambra.

Another instance of ornamental garden styles of architecture can be seen in the rauda, the garden cemetery in the Alhambra near the Calle Real Baja (the Royal Low Road) located near the mosque and the Patio of the Lions but largely covered over in the $16^{\text {th }}$ Century with the building of the Palace of Charles V. Muhammad II (1273-1302 CE) had been the first of the Nasrids to be buried in the Alhambran rauda; the subsequent two rulers, Muhammad III (1302-1309 CE) and Nasr (1309-1314 CE), found their resting places in the original Nasrid cemetery located on the same hill as the Alhambra but outside the walls to the south of the palace-city. ${ }^{8}$

${ }^{7}$ Ibn Khaldun, The Muqaddimah, 2: 295.

${ }^{8}$ See five articles contained in the Cuadernos de la Alhambra 36 (2000): Pedro Salmerón Escobar and María Cullel Muro, "La Rauda de la Alhambra, la memoria del lugar como base de la intervención," 71-110; José Javier Álvarez García, "Intervención arqueológico de apoyo a la restauración y puesta en valor de la Rauda," 111-153; Beatriz Martín Peinado, "La consolidación de los restos del antiguo zócalo de la Rauda de la Alhambra," 155-166; María José de la Torre López, Eduardo Sebastián Pardo, et al., "Estudio mineralógicopetrográfico de los materiales de construcción de la Rauda en la Alhambra," 167-180; and Inmaculada Alemán Miguel C. Botella, et al., "Estudio antropológico de los restos óseos humanos aparecidos en el 
The next sultan interred in the rauda, Isma'il I, had been a grandson of Muhammad II but through a collateral line and thus not a direct descendant of the founder of the dynasty, Muhammad I (Ibn al-Ahmar). A new line of descent began with Isma'il, and with his assassination in $1325 \mathrm{CE}$, his interment in the rauda can be interpreted as an attempt to more firmly establish his direct descendants as the rightful heirs to the Nasrid throne by having their remains within the walls of the Alhambra and thus forming a physical claim to legitimacy within the urban fabric of the palace-city. The lengthy epitaph on Isma'il's tombstone is recorded by Ibn al-Khatib in al-Lamba and makes several pointed references to the pure origins and exalted lineage of Abu al-Walid Isma'il (Molina and Casciaro, 1998). His commemoration concludes with the following verse, "But everything occurs by decree of God, whom no one can oppose, because His order is always contained (or gripped) between the käf and the num." Although such literary allusions to the greatness of God as well as the greatness (to a lesser degree, of course) of the recently departed one are not unique in medieval Islamic eulogistic writings, the particular circumstances of Nasrid political intricacies contribute an additional dimension of significance to such references. The next two Nasrid sultans, Muhammad IV (1325-1333 CE) and Yusuf I (1333-1354 CE) were both sons of Isma'il. Despite the fact that both of these men also perished due to assassination, during that ensuing twenty years, Isma'il's line of descent had been assured for his descendants as the future sultans of the Nasrid dynasty. ${ }^{10}$

A final ornamental water reflection of power and authority can be seen at the private palace complex adjacent to the Alhambra, the 'Generalife,' probably built during the time of the Nasrid sultan, Muhammad III. The space had been renovated by Muhammad's son, Isma'îl $\mathrm{I}$, in celebration of his victory over the Christians at the Battle of the Vega in the mountains not far from the city of Granada, in 1319 CE. ${ }^{11}$

The architectural style of the Generalife is typical of a garden space in the Islamic tradition with the important added dimension that all the water for the entire palace-city entered the Alhambra through the Acequia Real located at the southern end of the Generalife and leading into the medina area on the eastern side of the complex. Within the Generalife itself, the central space is the Patio of the Acequia, a rectangular courtyard with a reflecting pool down the center. A second water space can be found on the northern side of the garden area that contained a small oratory for prayer, although only a general outline of the religious space still exists. A mirador was later constructed near the space much later, in $1836 .{ }^{12}$

The Generalife is built at a slightly higher elevation than the Alhambra; therefore, an open corridor adjacent to the main courtyard of the Generalife runs along the western side and in the immediate sense looks down on the agricultural spaces, both ornamental and vegetal, located between the two palace regions. The Alhambra can be seen at a point slightly

cementerio de La Rauda," 181-190; seealso James Dickie, “The Hispano-Arab Garden, Its Philosophy and Function," Bulletin of the School of Oriental and African Studies 31 (1968), 15-26.

9 Ibid., 94. The kajf and the nün are letters of the Arabic alphabet that form the root of the verb kana, the closest Arabic gets to a verb meaning 'to be'. In this context, it is a poetic reference to the omnipotence of God.

10 Muhammad IV had been on military campaign when he was killed so was buried in Málaga; Yusuf I was assassinated in the mosque in the Alhambra and was buried in the rauda. Ibn al-Khatib in al-Ihata and alLamba is the most important primary source for Nasrid political events, and with his departure from the scene in 1370, knowledge of subsequent events is sketchy and vague.

${ }^{11}$ For a Christian perspective on the Battle of the Vega, see L.P. Harvey (1990, p.180-183).

12 Antonio Malpica Cuello, La Alhambra de Granada, 332-333. See also Jesús Bermúdez Pareja, "El Generalife después del incendio de 1958" 23. 
farther removed from the Generalife, and lastly the city of Granada itself can be seen beyond the palace-city. During the time of the Nasrids, the small palace at the northern end of the Patio of the Acequia consisted of only one story; alterations to the private entrance from the Alhambra, as well as the addition of a second floor, were made later after the Spanish conquest. ${ }^{13}$

Water in the use of gardens and around the Generalife is important for understanding not only the ornamental aspects of agricultural space but also as a food-producing enterprise. The Alhambra never managed to be a self-sufficient entity and always relied upon the adjacent city of Granada and outlying areas for foodstuffs; nevertheless, little substantive information is known regarding the amount of land under cultivation or the types of crops grown within and around the Nasrid palace-city. ${ }^{14}$ There is agricultural space located between the Alhambra and the Generalife used for vegetable gardens, and extensive agricultural holdings existed outside the walls of both entities; ongoing archeological work in these areas will hopefully reveal more information regarding how much of this land was under cultivation and/or what specific crops would have been cultivated in the surrounding areas of the Alhambra.

As a literary source, however, Ibn al-Khatib writes in al-Ihata and al-Lamba about the agricultural enterprises both inside and outside the Alhambra, reflecting not only the personal riches of the sultan but also the varieties of wealth found in the countryside of the Nasrid kingdom. He writes that the Kingdom of Granada, "is a sea of wheat and a mine of excellent cereals ... [where] the waters surround [the land], the air is healthy, the vegetable and flower gardens abundant; there are thick forests and many fragrant herbs and medicinal plants." He also mentions that the sultan's private lands "are of such value and high quality that the fortunes of kings would be necessary to pay the price for them." 15 Although Ibn al-Khatib has been known to exaggerate at times, it is true that the lands of the vega surrounding the Alhambra and the city of Granada consisted of prosperous fincas and densely populated villages, some three hundred in total, in which about fifty of those villages were large enough for their own congregational mosques. Ibn al-Khatib went on to report that the region was filled with magnificent houses and alquerias, many horses for both agricultural and military use, dovecots, hen houses, more than 130 water mills, and a great variety of foodstuffs, from fruits to spices and medicinal herbs. ${ }^{16}$

Despite Ibn al-Khatib's assertion of plenty, the Kingdom of Granada at times had to resort to imports of cereals. The constant influx of Muslim refugees from the north, on-going military threats from both the north (the Kingdom of Castile) and the south (North Africa), poor soil, and occasional drought or insect infestations made for frequent shortages and rampant inflation in the kingdom. ${ }^{17}$ Ibn Khaldun (1332-1406 CE), the famous $14^{\text {th }}$ Century North African traveler and contemporary of Ibn al-Khatib who did travel to Granada in the late 1350s, described differently the agricultural conditions in the Kingdom of Granada, and although he praises the Andalusis as people "most devoted to agriculture," he goes on to write,

\footnotetext{
${ }^{13}$ Interview and tour of the Alhambra with Dr. Antonio Malpica Cuello, Granada, Spain, 1998.

${ }^{14}$ Ibid. See also Antonio Malpica Cuello (2007); Ramón-Laca (1999); Vallvé (1982, 261-297).

15 Ibn al-Khatib, al-Lamba 41-43; Emilio Molina et al, Historia de los Reyes 8-11.

${ }^{16} \mathrm{Ibid}$.

${ }^{17}$ Ibid., 158. Arié writes that the Kingdom of Granada suffered from chronic shortages of cereals (wheat, barley, and millet) that continued through the $15^{\text {th }}$ Century.
} 
The Christians pushed the Muslims back to the sea coast and the rugged territory there, where (the soil) is poor for the cultivation of grain and little suited for (the growth of) vegetables. They themselves took possession of the fine soil and the good land. Thus, (the Muslims) had to treat the fields and tracts of land, in order to improve the plants and agriculture there. This treatment required expensive labour (products) and materials, such as fertilizer and other things that had to be procured. Thus, their agricultural activities required considerable expenditure. They calculated their expenditure in fixing their prices, and thus Spain has become an especially expensive region (Ibn Khaldun, 1967).

Cultural studies that consider the practical and daily use and management of water for the purposes of hygiene, religious observance, and agriculture are well-established. In addition, however, for an Islamic society, born and matured in arid environments, the uses of water as symbolism, as a reflection of the power and authority of the ruler, should also be considered, and all of these uses, both practical and symbolic, are demonstrated at the Alhambra.

\section{References}

Arié, R. (1992): El reino nasrí de Granada (1232-1492), Madrid, Editorial Mapfre.

Bermúdez-Pareja, J. (1974-75): El baño del Palacio de Comares en la Alhambra de Granada, disposición primitiva y alteraciones, Cuadernos de la Alhambra, 10-11: 99-122.

Cabanelas, D., and A. Fernández-Puertas (1978): Inscripciones poéticas del Generalife, Cuadernos de la Alhambra,14: 3-89.

Eguaras Ibáñez, J. (1988): Ibn Luyun: Tratado de Agricultura, Granada, Patronato de la Alhambra.

Fernandez-Puertas, A. (1997): The Alhambra, Vol. I, From the Ninth Century to Yüsuf I (1354), London, Saqi Books.

García-Gómez, E. (1985): Poemas árabes en los muros y fuentes de la Alhambra, Madrid, Instituto Egipcio de Estudios Islámicos en Madrid.

García-Gómez, E. (1975): Ibn Zamrak, El poeta de la Alhambra, Granada, Patronato de la Alhambra 22.

Glick, T. F. (2007): Paisajes de conquista, cambio cultural y geográfico en la España medieval, Valencia, Universitat de València.

Glick, T. F. (1992): Tecnología, ciencia y cultura en la España medieval, Madrid, Alianza Editorial.

Glick, T. F., and H. Kirchner. (2000): Hydraulic Systems and Technologies of Islamic Spain: History and Archaeology, in P. Squatriti, Ed., Working with Water in Medieval Europe, Technology and Resource-Use, E.J. Brill, pp. 267-329.

Gómez Román, A., J. Rodríguez Domingo, and J. Bermúdez Lopez. 1992): La Fuente de los Leones en la Alhambra como símbolo de poder, Cuadernos de la Alhambra, 28:167-177.

Grabar, O. (1976): The Alhambra, Cambridge, MA, Harvard University Press.

Ibn Khaldun. (1958): Muqaddimah, Kitab al-Ibar, An Inroduction to History, F. Rosenthal, Trans., London, Routledge \& Kegan Paul.

Ibn Khaldun (1967): The Muqaddimah, An Introduction to History, Franz Rosenthal, trans. N.J. Dawood, ed. (Princeton, NJ: Princeton University Press,) 277. 
Ibn al-Khatib, L. (1998): Al-Lamba al-badriyya fi al-dawlat al-nasriyyat (El Resplandor de la luna llena, Historia de los reyes de la Alhambra, J. M. Casciaro, Trans., Granada, Universidad de Granada.

Malpica Cuello, A. (2012): El agua en la agricultura, agroecosistemas y ecosistema en la economía rural andalusí, Vinculos de Historia, 1:31-44.

Malpica Cuello, A. (1994): El agua en al-Andalus, un debate historiográfico y una propuesta de análisis, Semana de Estudios Medievales de Nájera, 5:65-85.

Malpica Cuello, A. (2007): La Albambra, ciudad palatina nazarí, Málaga, Editorial Sarriá.

Malpica Cuello, A. (2002): La Alhambra de Granada, un estudio arqueológico, Granada, Editorial de la Universidad de Granada.

Menéndez de Luarca, L. (1999): Plantas cultivadas en los siglos XVI y XVII en la Alhambra y el Generalife, Cuadernos de la Alhambra, 35:49-53.

Molina, E. and Casciaro, J.M. eds. (1998): Historia de los Reyes de la Alhambra, Granada, Spain, Universidad de Granada.

Najjaj, A. (2005): The Alhambra in Comparative Perspective: Towards a Definition of Palace-Cities. Unpublished doctoral dissertation, Boston University.

Nuere, E. (1986): Sobre el pavimento del Patio de los Leones, Cuadernos de la Alhambra, 22:87-93.

Pavón Maldonado, B. (1990): Tratado de arquitectura hispanomusulmana, Madrid, Consejo Superior de Investigaciones Científicas.

Ramón-Laca Menéndez de Luarca, L. (1999): "Plantas cultivadas en los siglos XVI y XVII en la Alhambra y el Generalife," Cuadernos de la Alhambra 35: 49-53.

Torres-Balbás, L. (1945): La mezquita real de la Alhambra y el baño frontero, Al-Andalus, 10: 196-214.

Torres-Balbás, L. (1959): Letrinas y bacines, Al-Andalus, 24: 225.

Vallvé, J (1982): La agricultura en al-Andalus, Al-Qantara, Revista de Estudios Árabes 3: 261297. 